\title{
Solidification of REDC Organics and Airborne Release Fraction Measurements
}

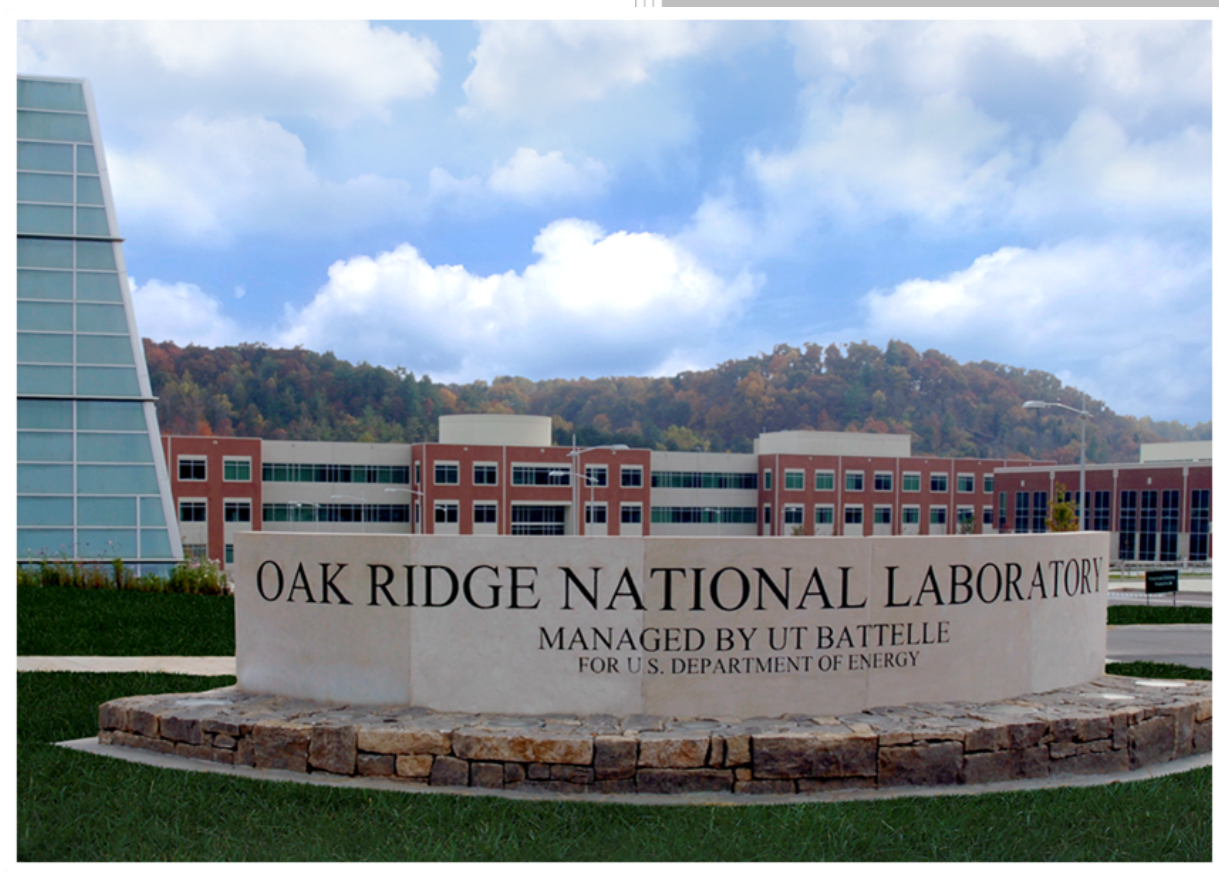

Approved for public release.

Distribution is unlimited.

Paul Taylor

Catherine Mattus

Trenton Walker

February 2020 


\section{DOCUMENT AVAILABILITY}

Reports produced after January 1, 1996, are generally available free via US Department of Energy (DOE) SciTech Connect.

Website www.osti.gov

Reports produced before January 1, 1996, may be purchased by members of the public from the following source:

National Technical Information Service

5285 Port Royal Road

Springfield, VA 22161

Telephone 703-605-6000 (1-800-553-6847)

TDD 703-487-4639

Fax 703-605-6900

E-mail info@ntis.gov

Website http://classic.ntis.gov/

Reports are available to DOE employees, DOE contractors, Energy Technology Data Exchange representatives, and International Nuclear Information System representatives from the following source:

Office of Scientific and Technical Information

PO Box 62

Oak Ridge, TN 37831

Telephone 865-576-8401

Fax 865-576-5728

E-mail reports@osti.gov

Website http://www.osti.gov/contact.html

This report was prepared as an account of work sponsored by an agency of the United States Government. Neither the United States Government nor any agency thereof, nor any of their employees, makes any warranty, express or implied, or assumes any legal liability or responsibility for the accuracy, completeness, or usefulness of any information, apparatus, product, or process disclosed, or represents that its use would not infringe privately owned rights. Reference herein to any specific commercial product, process, or service by trade name, trademark, manufacturer, or otherwise, does not necessarily constitute or imply its endorsement, recommendation, or favoring by the United States Government or any agency thereof. The views and opinions of authors expressed herein do not necessarily state or reflect those of the United States Government or any agency thereof. 
Isotope and Fuel Cycle Technology Division

\title{
SOLIDIFICATION OF REDC ORGANICS AND AIRBORNE RELEASE FRACTION MEASUREMENTS
}

\author{
Paul Taylor \\ Catherine Mattus \\ Trenton Walker
}

February 2020

Prepared by

OAK RIDGE NATIONAL LABORATORY

Oak Ridge, TN 37831-6283

managed by

UT-BATTELLE, LLC

for the

US DEPARTMENT OF ENERGY

under contract DE-AC05-00OR22725 
This page intentionally left blank 


\section{CONTENTS}

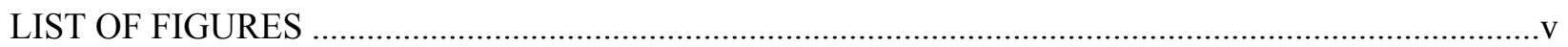

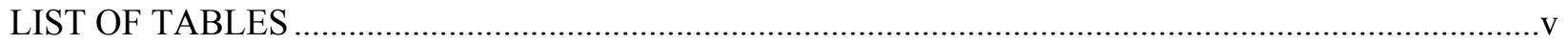

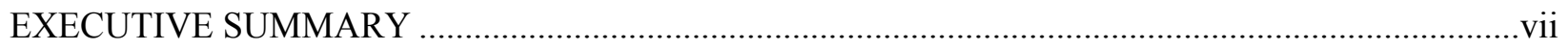

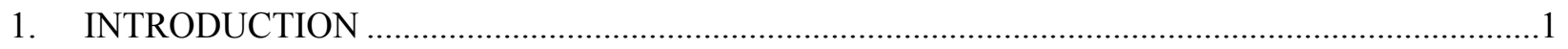

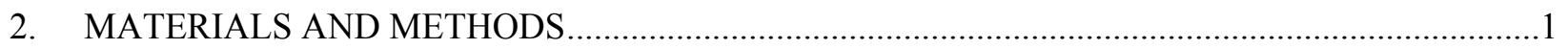

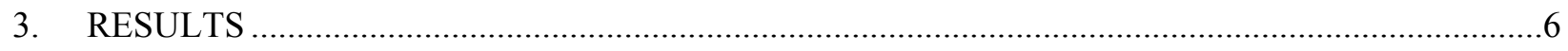

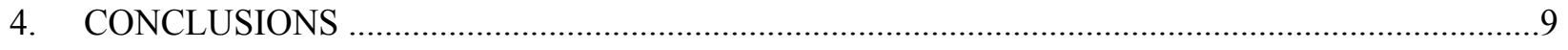

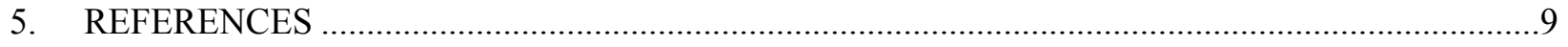


This page intentionally left blank 


\section{LIST OF FIGURES}

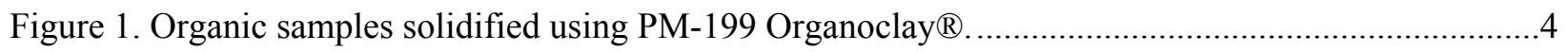

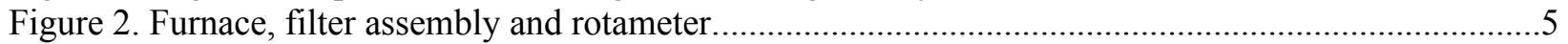

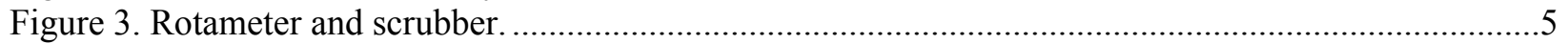

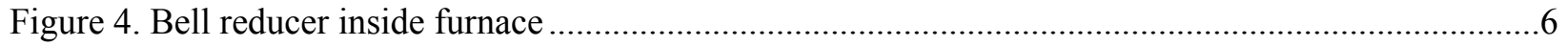

Figure 5. Examples of grouted waste forms - $1 M$ HDEHP (L), $2 M$ HDEHP (center), and TBP (R)

Figure 6. Typical temperature profile for fire scenario testing. ............................................................

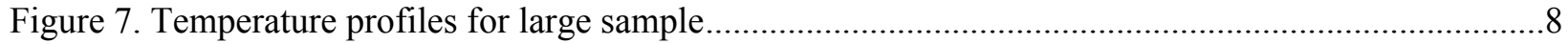

Figure 8. Photos of large grout samples before $(\mathrm{L})$ and after $(\mathrm{R})$ furnace test. ......................................

\section{LIST OF TABLES}

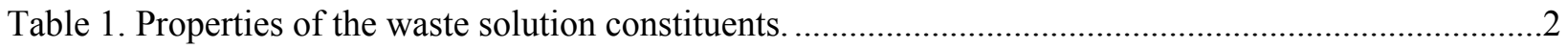

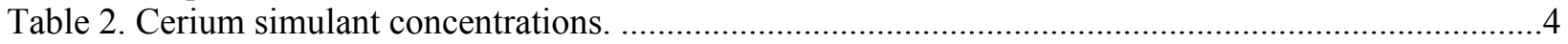

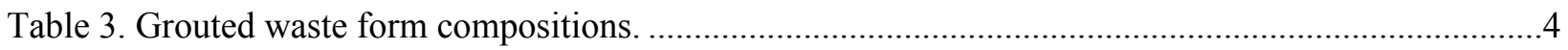

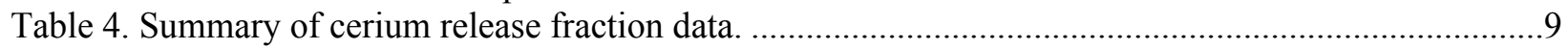


This page intentionally left blank 


\section{EXECUTIVE SUMMARY}

The Radiochemical Engineering Development Center (REDC) generates various liquid organic wastes from processing irradiated targets to recover heavy elements. In the past, these organics were discharged to the Oak Ridge National Laboratory (ORNL) liquid low-level waste (LLLW) system, along with the aqueous waste. Because of a reduction in aqueous LLLW from other ORNL generators and an increase in the radionuclide concentration, particularly ${ }^{238} \mathrm{Pu}$, in the organic waste stream, the organics can no longer be discharged to the LLLW system. The plan is to solidify the liquid organic waste for disposal as solid debris waste. The documented safety analysis for REDC uses an airborne release fraction of $5 \times 10^{-4}$ with a respirable fraction of 0.2 for plutonium and other actinides from packaged solid debris waste during a fire scenario, for an overall airborne release fraction/respirable fraction of $10^{-4}$.

Solidifying the organic liquids, either by using PM-199 Organoclay ${ }^{\circledR}$ or by grouting, would produce solid waste forms with no free liquid, which should qualify for disposal at the Waste Isolation Pilot Plant. The use of Organoclay would be much simpler to implement inside a hot cell. Granular Organoclay can be added to the organic waste solutions until there is a dry layer on top of the liquid and then allowed to cure for a few hours. Grouting the liquids would require using multiple ingredients and mixing steps. Both methods produced waste forms that trapped cerium, as a surrogate for plutonium, inside the waste, with airborne release fractions during fire scenario tests of well below the $10^{-4}$ limit. 
This page intentionally left blank 


\section{INTRODUCTION}

The Radiochemical Engineering Development Center (REDC) at Oak Ridge National Laboratory (ORNL) generates various liquid organic wastes from processing irradiated targets to recover heavy elements. In the past, these organics were discharged to the ORNL liquid low-level waste (LLLW) system, along with the aqueous waste. Because of a reduction in aqueous LLLW from other ORNL generators and an increase in the radionuclide concentration, particularly ${ }^{238} \mathrm{Pu}$, in the organic waste stream, the organics can no longer be discharged to the LLLW system. The plan is to solidify the liquid organic waste for disposal as solid debris waste. Various methods of solidifying the waste were tested, including absorption into a clay-based granular sorbent and various grout-based formulations. Most of the waste forms tested would meet the waste acceptance criteria for disposal at the Waste Isolation Pilot Plant as transuranic waste, but there were questions about whether they would meet REDC plutonium release criteria during a fire. The documented safety analysis (DSA) for REDC uses an airborne release fraction of $5 \times 10-4$ with a respirable fraction of 0.2 for plutonium and other actinides from packaged solid debris waste during a fire scenario, for an overall airborne release fraction/respirable fraction of $10^{-4}$.

Experimental results for plutonium release fractions from burning various materials have been compiled by the Department of Energy [DOE, 1994]. Combustion of organic liquids gave an average airborne release fraction of $6 \times 10^{-3}$, and combustion of surface-contaminated solids (e.g., paper, plastic) gave an average airborne release fraction of $5 \times 10^{-4}$. Burning of $30 \%$ tri- $n$-butyl phosphate (TBP) in kerosene gave release fractions for cerium, which is commonly used as a plutonium surrogate, of 5.6-7.7 $\times 10^{-3}$ [Mishima and Schwendiman, 1973]. We could not find published release fraction measurements for solidified organic wastes that could be used to prove that the proposed waste forms would not exceed the airborne release fraction/respirable fraction used in the REDC DSA.

The tests described in this report evaluated many different grout-based formulations to solidify plutonium-containing organic waste liquids, and the best ones were shown to produce monolithic, fairly homogeneous solids. Sorption of the organics on PM-199 Organoclay ${ }^{\circledR}$ (Colloid Environmental Technologies Company [Cetco], United Kingdom) was also evaluated. The Organoclay formed a soft, rubbery solid, while various grout-based formulations produced harder solids. None of the solidified waste forms contained any free liquid. We first assumed that any of the solidified waste forms would release less plutonium during a fire than the contaminated debris (e.g., paper, plastic) that is routinely generated in the REDC hot cells and meets the airborne release fraction/respirable fraction used in the DSA. However, when small samples of the solidified waste forms were ignited using a torch, organic vapors from the solids burned, even after the torch was removed. The grouted solids burned for less than a minute after the torch was removed, but the Organoclay solids kept burning for several minutes, presumably until all of the volatile organics in the waste form evaporated. It is possible that plutoniumcontaining organics could migrate to the surface of the solidified waste form and release plutonium into the air as they burn. In order to estimate the plutonium release fraction from the waste forms, the airborne release fraction for cerium, as a surrogate for plutonium, was measured.

\section{MATERIALS AND METHODS}

The primary liquid organic waste solutions generated at REDC are PUREX solution, $30 \%$ tributyl phosphate (TBP) in Exxsol D60 ${ }^{\circledR}$ (Exxon Corp., Parkway Spring, TX), a straight chain, aliphatic hydrocarbon, and CLEANEX solution, $1 \mathrm{M}$ Di-(2-ethylhexyl) phosphoric acid (HDEHP) in Exxsol D60.

Selected properties of each constituent are shown in Table 1. All of the constituents are classified as combustible, but not flammable; however, the Exxsol D60 ignites much more easily than do the extractants. 
Table 1. Properties of the waste solution constituents.

\begin{tabular}{ccc}
\hline Chemical & Boiling point $\left({ }^{\circ} \mathbf{C}\right)$ & Flash point $\left({ }^{\circ} \mathbf{C}\right)$ \\
\hline Exxsol D60 & $189-210$ & 64 \\
Tributyl phosphate & 289 & 146 \\
HDEHP & 393 & 196 \\
\hline
\end{tabular}

The first solidification method tested was to add PM-199 Organoclay, a granular, clay-based sorbent modified to absorb organics, to each of the organic solutions. The Organoclay was added to the organic compound until a dry layer of Organoclay was present on top of the organic. The organic solidifies into a rubbery solid. No mixing was required, so Organoclay was very easy to use. The solidified waste volume was about twice that of the starting organic volume.

Numerous tests were performed to find a grout-based formulation that would solidify the organic solutions. Since liquid organics do not combine with cement-based grouts, various sorbents were tested that would absorb the organic liquid into a loose solid that could then be mixed with the grout. The sorbent must be hydrophobic, so that it doesn't absorb water from the grout mixture and prevent proper curing of the cement. Many different sorbents were tested; the ones that worked best were TIXOGEL-VZ (BYK USA Inc., Wallingford, CT), an organophilic phyllosilicate; ENOVA Aerogel IC3100 and Cabot Aerogel P300 (Cabot Corp., Boston, MA), which are both modified synthetic amorphous silica; and Sepabeads SP-207 (Mitsubishi Chemical Corp., Tokyo, Japan), brominated styrene-divinylbenzene beads. The organic solution and sorbent were mixed together and then the mixture was combined with a cement/water slurry. Adding a small amount of Master Glenium 7920 ${ }^{\circledR}$ (BASF Corp., Cleveland, OH), a polycarboxylate formulation that is added to the water before mixing with the cement, reduced the amount of water needed to obtain an easily mixable cement slurry and reduced the chance of free water after the organic/cement mixture solidified. Typical ratios used were $30 \mathrm{~g}$ TIXOGEL-VZ in $100 \mathrm{~g}$ PUREX solution, mixed with a slurry of $175 \mathrm{~g}$ cement in $72 \mathrm{~g}$ water plus $1 \mathrm{~g}$ Glenium. This formulation worked well for the PUREX solution, yielding a mixture that was relatively easy to stir when wet and that set up with no free water.

When the same formula was used with the CLEANEX solution, the mixture thickened very rapidly, and it was difficult to get the organic/sorbent and water/cement/Glenium slurries mixed adequately to solidify all of the organic slurry. HDEHP is more acidic than TBP, so tests were made using $\mathrm{Ca}(\mathrm{OH})_{2}$ and $\mathrm{NaOH}$ to neutralize the acid prior to mixing with the sorbent. The neutralization of $1 M \mathrm{HDEHP}(34 \mathrm{wt} \%)$ simulant with $\mathrm{Ca}(\mathrm{OH})_{2}$ produced a very think slurry, which was difficult to mix with the sorbents; however, we found that it could be incorporated into the cement/water slurry. Adding expanded perlite, a low-density amorphous volcanic glass, prevented the formation of free water during curing. Typical ratios used for solidifying $1 \mathrm{MHDEHP}$ were $90 \mathrm{~g} \mathrm{Ca}(\mathrm{OH})_{2}$ in $100 \mathrm{~g}$ CLEANEX solution, mixed with a slurry of $200 \mathrm{~g}$ cement in $54 \mathrm{~g}$ water plus $1 \mathrm{~g}$ Glenium, and then with $12 \mathrm{~g}$ perlite. The CLEANEX solution might be stored in a waste tank for an extended period of time prior to solidification, which would allow some of the Exxsol D60 to evaporate, increasing the concentration of HDEHP. A $2 M$ HDEHP (66 wt \%) solution was tested as a worst case. The amounts of the various additives needed to be adjusted, but the mixture would solidify without any free water. Typical ratios used for solidifying $2 M$ HDEHP were $77 \mathrm{~g}$ $\mathrm{Ca}(\mathrm{OH})_{2}$ in $100 \mathrm{~g}$ organic solution, mixed with a slurry of $200 \mathrm{~g}$ cement in $54 \mathrm{~g}$ water plus $1.1 \mathrm{~g}$ Glenium, and then with $19 \mathrm{~g}$ perlite.

The sequence of addition of the components included two separate mixes to be made in two different containers. In hot cell operation, the tasks need to be as simple as possible. Therefore, some tests were performed to determine if the solidification could be done in only one container, which would be the disposal container. 
A satisfactory grout was obtained using this sequence:

- Add the liquid organic waste to the container.

- Add the $\mathrm{Ca}(\mathrm{OH})_{2}$ powder.

- Mix manually to obtain a homogeneous slurry. (The slurry becomes hot and needs to cool down before the next step; the mixture becomes thicker after cooling.)

- Meanwhile, measure the quantity of water necessary and add the water reducer admixture (Glenium 7920). Disperse the Glenium to obtain a homogeneous color of the solution.

- Continue the operation using an electric mixer, running at a relatively low speed ( 140 RPM) in the container holding the neutralized organic slurry.

- While the mixer is running, add an aliquot of the water + Glenium mixture, around $1 / 5$ of the total.

- Just after the water addition, add about 1/5 of the cement. Mix until it looks homogeneous.

- Introduce another $1 / 5$ aliquot of water followed by $1 / 5$ of the cement. Mix until homogeneous.

- Repeat until all water and cement are added.

- Continue mixing for $\sim 30$ seconds after a homogeneous mix is obtained.

- Stop the mixer

The solidified test specimens were heated in an oven to $600^{\circ} \mathrm{C}$ and then held at that temperature for 1 hour to simulate a fire scenario at the REDC and to determine the impact on the physical properties of the specimens.

Following the fire scenario tests, it was determined that there was not enough information to confirm that plutonium would not be released above allowable limits as the organic in the specimens burned. A measurement of the release fraction would be required. Cerium is often used as a simulant for plutonium in bench-scale testing, and cerium nitrate hexahydrate $\left[\mathrm{Ce}\left(\mathrm{NO}_{3}\right)_{3} \cdot 6 \mathrm{H}_{2} \mathrm{O}\right]$ was added to the organic solutions that were solidified to prepare the surrogate waste forms for these tests. The waste forms were subjected to the designated fire scenario of $600^{\circ} \mathrm{C}$ for 1 hour, and any cerium in the offgas was trapped using a quartz filter followed by a scrubber containing $0.1 \mathrm{M} \mathrm{NaOH}$; that is the same setup used by Mishima and Schwendiman, [1973].

Solutions of $1 M$ Di-(2-ethylhexyl) phosphoric acid (HDEHP) in Exxon Exxsol D60, $2 M$ HDEHP in D60, and 30\% tri- $n$-butyl phosphate (TBP) in D60 were prepared, and cerium nitrate was added at near the maximum solubility limit. The resulting solutions were translucent. The concentration of cerium in the three simulants is shown in Table 2. The REDC uses 30\% TBP in D60 to extract plutonium from dissolved targets and uses $1 M$ HDEHP in D60 to reduce the amount of plutonium in aqueous waste solutions. D60 can evaporate from the used extractant solutions during storage prior to disposal, so a $2 \mathrm{M}$ HDEHP solution was also tested as a worst-case scenario for HDEHP concentration. 
Table 2. Cerium simulant concentrations.

\begin{tabular}{cc}
\hline Simulant & {$[\mathbf{C e}]$ in $\mathbf{~ m g} / \mathbf{L}$} \\
\hline $1 M$ HDEHP-Ce & 10,100 \\
$2 M$ HDEHP-Ce & 8,000 \\
$30 \%$ TBP-Ce & 23,000 \\
\hline
\end{tabular}

The cerium-loaded HDEHP simulants were solidified using the same recipes as before, and the mixing was done manually. The composition of the waste forms is shown in Table 3.

Table 3. Grouted waste form compositions.

\begin{tabular}{|c|c|c|c|c|c|c|}
\hline \multirow[b]{2}{*}{ Simulant } & \multicolumn{2}{|c|}{$1 M$ HDEHP-Ce } & \multicolumn{2}{|c|}{$2 M$ HDEHP-Ce } & \multicolumn{2}{|c|}{ 30\% TBP-Ce } \\
\hline & $\begin{array}{c}\text { Weight } \\
\text { (g) }\end{array}$ & $\begin{array}{c}\text { Weight } \\
(\%)\end{array}$ & $\begin{array}{c}\text { Weight } \\
\text { (g) }\end{array}$ & $\begin{array}{c}\text { Weight } \\
(\%)\end{array}$ & $\begin{array}{l}\text { Weight } \\
\text { (g) }\end{array}$ & $\begin{array}{c}\text { Weight } \\
(\%)\end{array}$ \\
\hline Simulant & 108.2 & 19.8 & 101.1 & 21.5 & 97.5 & 26.5 \\
\hline $\mathrm{Ca}(\mathrm{OH})$ & 97.2 & 17.8 & 78.3 & 16.7 & - & - \\
\hline Tixogel VZ & - & - & - & - & 28.9 & 7.8 \\
\hline $\begin{array}{l}\text { Ordinary Portland } \\
\text { cement Type III }\end{array}$ & 216.4 & 39.7 & 203.8 & 43.4 & 171.4 & 46.5 \\
\hline Water & 117.3 & 21.5 & 72.7 & 15.5 & 69.8 & 18.9 \\
\hline Glenium 7700 & 1.5 & 0.3 & 1.7 & 0.4 & 1.0 & 0.3 \\
\hline Perlite & 4.9 & 0.9 & 12.3 & 2.6 & - & - \\
\hline
\end{tabular}

The samples were packed into plastic molds and cured at room temperature for 16 days before testing, with the plastic mold removed.

Samples of the cerium-loaded simulants were also solidified using PM-199 Organoclay, which is a granular solid. The PM-199 was simply poured into the organic liquids until there was a dry layer on top of the sample. This process would be much easier to perform inside a hot cell than grouting would be. Two samples were prepared for each simulant, and two blanks were prepared using $1 M$ HDEHP in Exxsol D60 with no cerium nitrate. The Organoclay samples were prepared by adding $25 \mathrm{~mL}$ of simulant, followed by $40.5 \mathrm{~g}$ of sorbent - just enough to cover the liquid - to a stainless steel cup. The samples were stored uncovered for 7 days before testing.

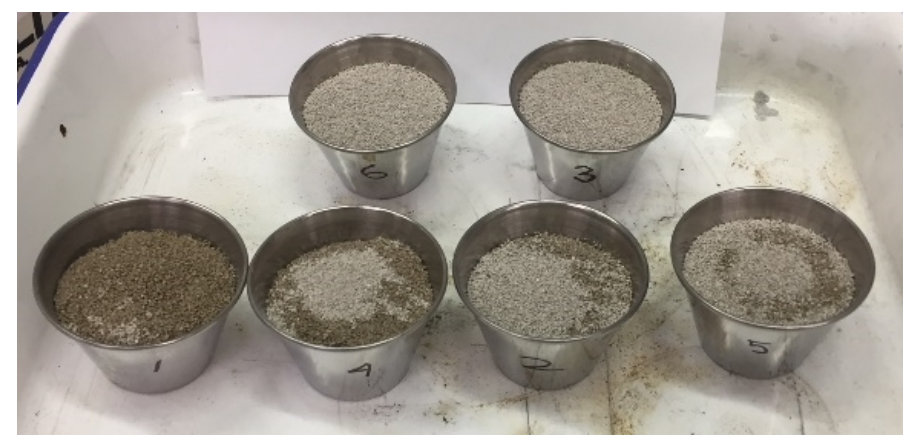

Figure 1. Organic samples solidified using PM-199 Organoclay®. 
The fire scenario testing was performed by placing a solidified organic sample under a $3 \mathrm{in} . \times 1 \mathrm{in}$. bell reducer in a stainless steel pan. The bell reducer was connected to an offgas system and was held about 1 in. above the pan to provide an airflow path. The building vacuum system was used to pull air through the gap beneath the bell reducer, past the sample, and then through a filter assembly, a scrubber, and a rotameter to capture any cerium that was volatilized during testing. The filters were $90 \mathrm{~mm}$ O.D. quartz filters designed to collect $>10$ micron particulates. The scrubber contained $500 \mathrm{~mL}$ of $0.1 \mathrm{M} \mathrm{NaOH}$. The desired air flow rate was $1 \mathrm{ft}^{3} / \mathrm{min}$; however, soot buildup on the quartz filter sometimes reduced the flow rate. Figures 2-4 show the system used to test the cerium release fraction from the solidified organic samples. The test specimen was placed under the bell reducer, the air flowrate was adjusted to $1 \mathrm{ft}^{3} / \mathrm{min}$, and then the furnace was turned on at a set point of $600^{\circ} \mathrm{C}$. After the furnace had reached the set point, the test was run for an additional hour.

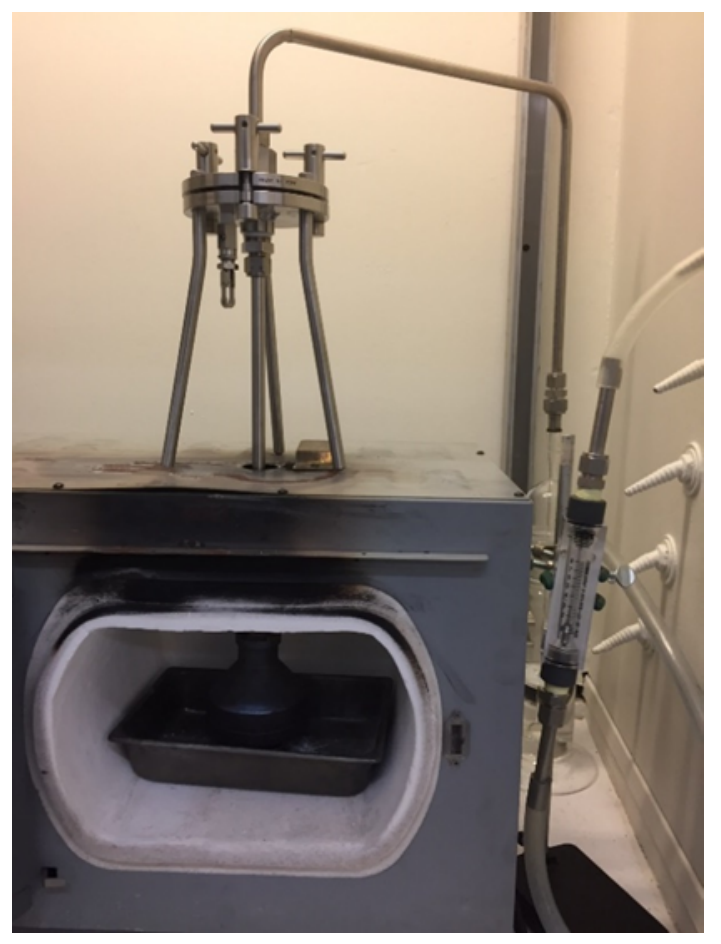

Figure 2. Furnace, filter assembly and rotameter.

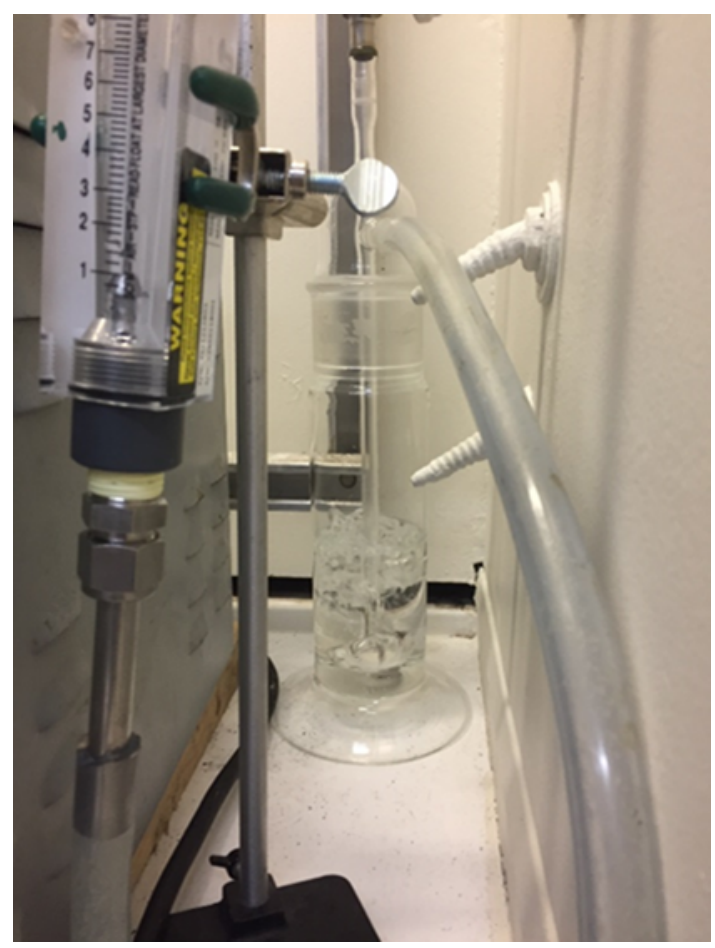

Figure 3. Rotameter and scrubber. 


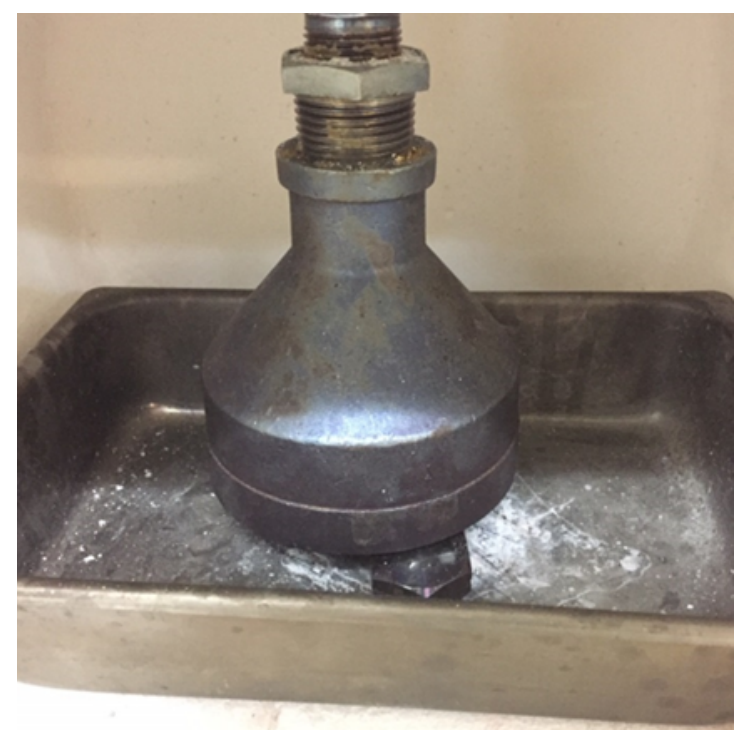

Figure 4. Bell reducer inside furnace

After each test, the quartz filter from the filter assembly was removed and leached with $50 \mathrm{~mL}$ of $70 \%$ $\mathrm{HNO}_{3}$ and rinsed several times with deionized $\mathrm{H}_{2} \mathrm{O}$ to recover the cerium captured by the filter. The nitric acid and rinse solutions were then added to the $0.1 \mathrm{M} \mathrm{NaOH}$ solution used in the scrubber. The resulting solution was analyzed at the ORNL Radioactive Materials Analysis Laboratory to determine the amount of cerium collected in the offgas system. This was compared with the amount of cerium originally in the starting sample to determine the release fraction. Several samples of the liquid cerium-containing organic solutions were also tested to determine the effectiveness of the solidification processes in reducing cerium release. During the runs, a thermocouple was used to determine the temperature just above the sample, and the furnace temperature was monitored. The flow rate of the offgas was also monitored to ensure that the offgas was being captured. Temperature and flow data for each run can be found in Appendix A.

\section{RESULTS}

Examples of the grouted waste forms that were produced are shown in Figure 5: $1 M$ HDEHP in D60 on the left, $2 M$ HDEHP in D60 in the center, and 30\% TBP in D60 on the right. All of the waste forms that used the optimized formulations described were fairly strong monoliths. The specimens were about $6 \mathrm{~cm}$ O.D. and $3 \mathrm{~cm}$ tall.
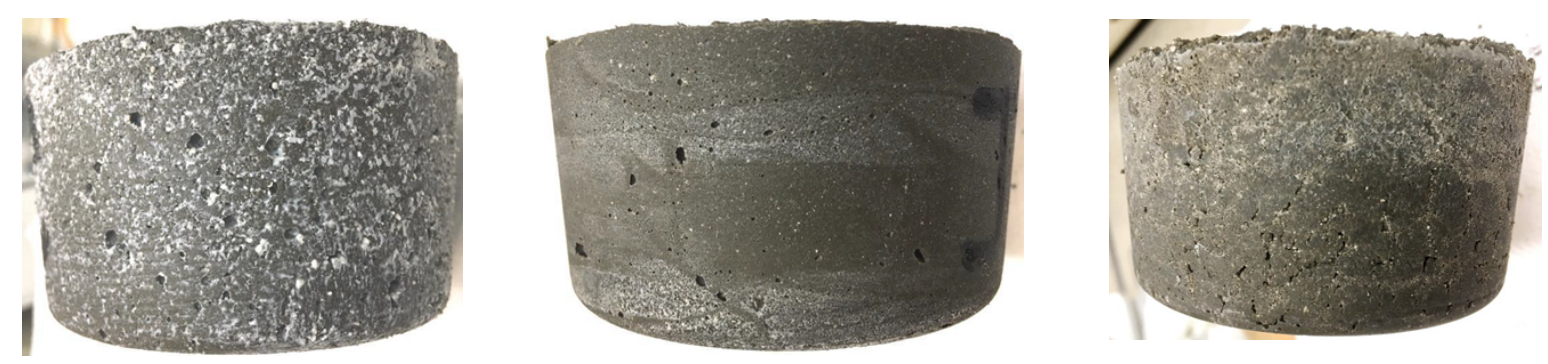

Figure 5. Examples of grouted waste forms-1 $M$ HDEHP (L), $2 M$ HDEHP (center), and TBP (R). 
A thermocouple was inserted about $0.5 \mathrm{~cm}$ into the top of the waste form to record the temperature of the sample , and the furnace temperature was recorded. After being heated to $600^{\circ} \mathrm{C}$ for 1 hour, the waste forms were harder but more brittle. Figure 6 shows a typical graph of the temperatures over time. Initially the sample temperature lagged the furnace temperature, but then the organic vapor ignited, and the surface of the sample became hotter than the furnace. The vapor burned for about 20 minutes, as it continued to evaporate from the interior of the waste form, and then the fire expired after the organic was depleted.

One larger waste form was produced using $1 \mathrm{M}$ HEDHP solution and the same ratio of solidification agents. The mixture contained $1002 \mathrm{~g}$ organic solution, $901 \mathrm{~g} \mathrm{Ca}(\mathrm{OH}) 2,121 \mathrm{~g}$ perlite, $2008 \mathrm{~g}$ cement powder, $10.5 \mathrm{~g}$ Glenium, and $540 \mathrm{~g}$ water. The wet grout was packed into a stainless steel pot and cured in situ. This sample was more representative of the waste forms that would be produced at REDC, which would be left inside the containers in which they were prepared. The grout sample was about $23 \mathrm{~cm}$ O.D. and $8 \mathrm{~cm}$ tall. This sample was exposed to the same fire scenario test, with thermocouples inserted into the center of the monolith (T-1) and $2 \mathrm{~cm}$ below the top of the monolith (T-2). Figure 7 shows the temperature profiles for this test. The organic vapor ignited about 30 minutes after the furnace was turned on, at a furnace temperature of about $330^{\circ} \mathrm{C}$. The furnace shut down about 15 minutes after the flames started, so the thermocouple readings inside the furnace were no longer displayed. The flames continued for about 150 minutes before self-extinguishing when the organics were depleted.

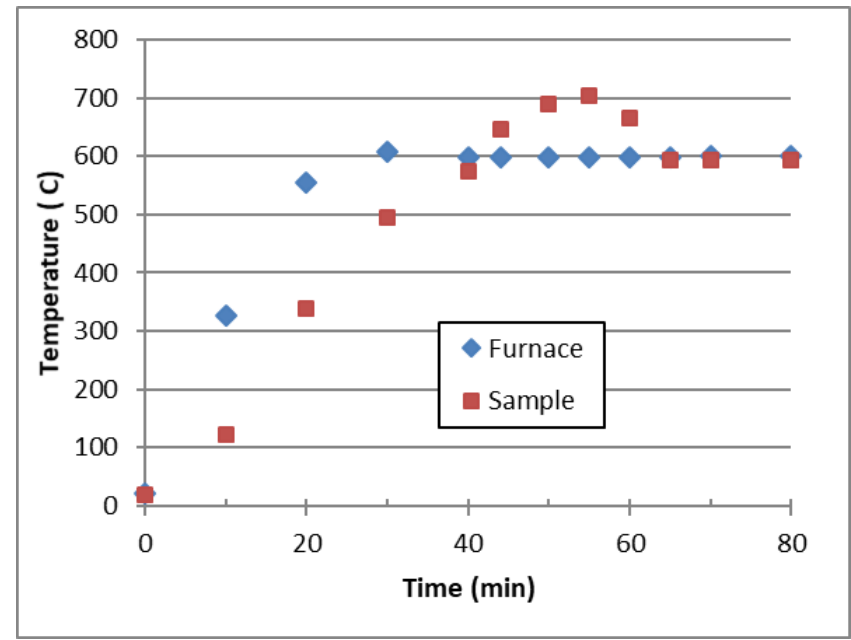

Figure 6. Typical temperature profile for fire scenario testing. 


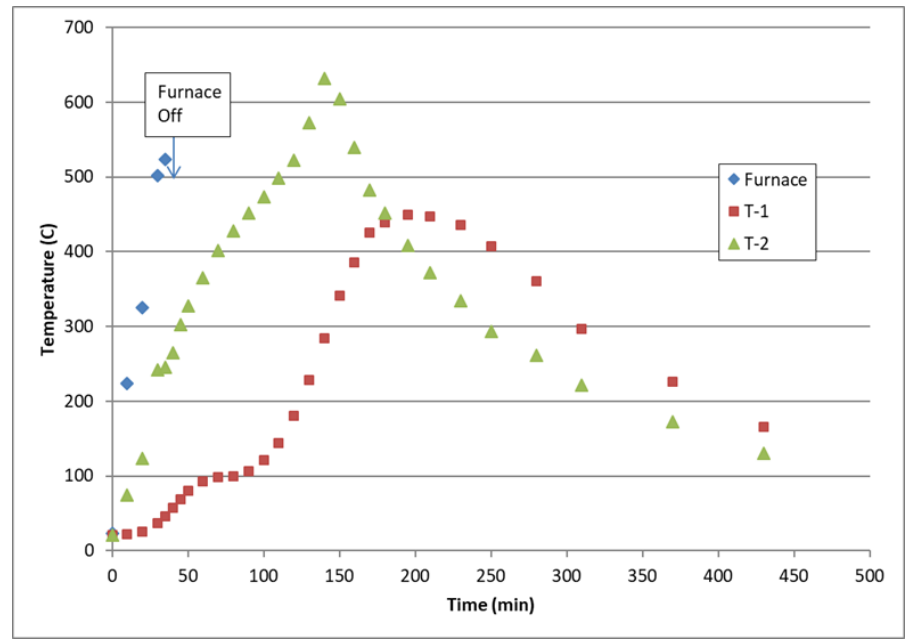

Figure 7. Temperature profiles for large sample

Figure 8 shows photos of the large sample before and after the furnace test. The grout plus the pan weighed $6057 \mathrm{~g}$ after curing and $4725 \mathrm{~g}$ after the furnace test; so the weight loss was $1332 \mathrm{~g}$, which is higher than the $1002 \mathrm{~g}$ of organic compound in the mixture. The extra weight loss must have resulted from evaporated moisture and/or chemical reactions during the furnace test.
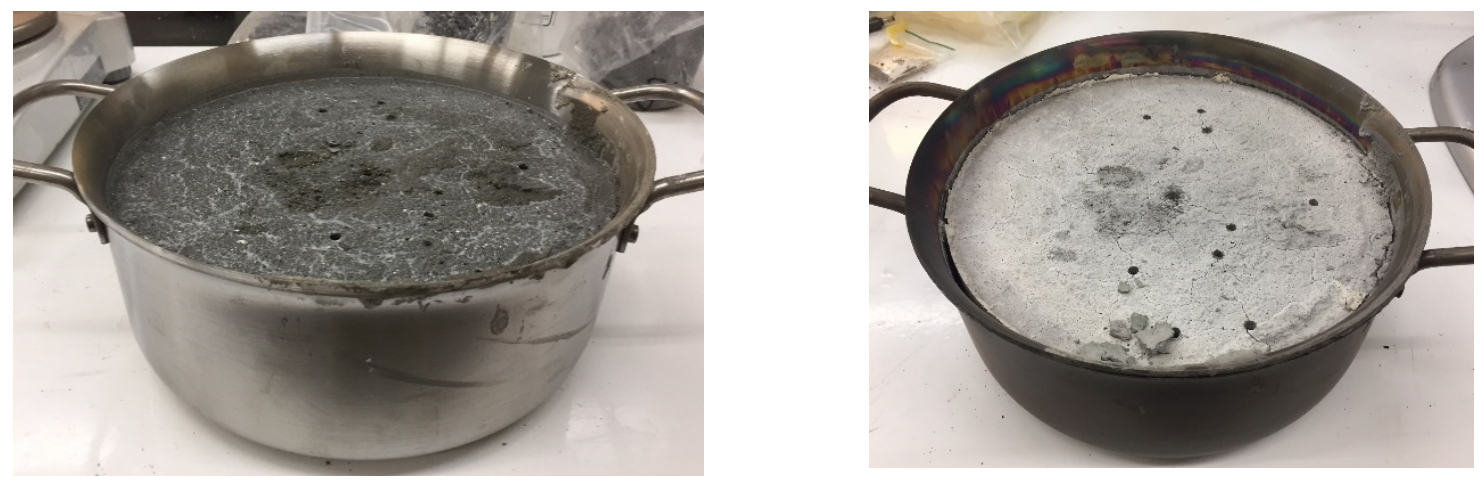

Figure 8. Photos of large grout samples before (L) and after (R) furnace test.

The release fractions obtained from these tests indicate that all of the solidification techniques would be effective in mitigating risks associated with plutonium release during a fire. Release fractions for runs performed using the solidified samples were typically on the order of $10^{-5}$ to $10^{-6}$, which would be an acceptable release fraction to meet the REDC DSA. The release fraction is calculated by dividing the cerium amount collected from the offgas (cerium concentration $\times$ liquid volume [filter leach solution plus scrubber solution]) by the cerium amount in the starting solidified waste form (see Table 2). As expected, solidifying the organic solutions had a significant impact on release fraction. Release fractions for runs performed on the liquid extractant solutions (runs 10-12) were about an order of magnitude higher than for those performed using solidified samples; and they were similar to, but lower than, the results published by Mishima and Schwendiman. The cerium release fraction for the Exxsol D60 sample that contained cerium (run 9) was about an order of magnitude higher than for the liquid samples containing the extractants (HDEHP or TBP). Note that cerium was also measured in the offgas from the liquid and solidified samples that did not contain cerium (runs 1 and 2). These two runs were performed before any cerium-containing samples were used in the test system, so residual contamination in the offgas system from earlier runs could not be the source. The results listed for runs $1 \mathrm{~A}$ and $2 \mathrm{~A}$ are a reanalysis of the 
combined scrubber solution and acid leach for runs 1 and 2 . The source of the cerium in these analyses is not known, and these could be false positives from the analysis. These results could indicate that the actual release fractions reported for the solidified samples may be lower than calculated. Runs 13 and 14 are repeats of runs 3 and 6, respectively. The results for all runs are summarized in Table 4.

Table 4. Summary of cerium release fraction data.

\begin{tabular}{|c|c|c|c|c|}
\hline Run no. & Solution & $\begin{array}{c}\text { Solidification } \\
\text { method }\end{array}$ & $\begin{array}{c}{[\mathrm{Ce}] \text { in solution }} \\
(\mathrm{ug} / \mathrm{L})\end{array}$ & Release fraction \\
\hline 1 & $1 M$ HDEHP, no Ce & $\begin{array}{l}\text { Not applicable } \\
\text { (NA) }\end{array}$ & 0.0028 & NA \\
\hline 2 & $1 M$ HDEHP, no Ce & Organoclay & 0.0042 & NA \\
\hline $1 \mathrm{~A}$ & $1 M$ HDEHP, no Ce & NA & 0.00179 & NA \\
\hline $2 \mathrm{~A}$ & $1 M$ HDEHP, no Ce & Organoclay & 0.00958 & NA \\
\hline 3 & $1 M \mathrm{HDEHP}+\mathrm{Ce}\left(\mathrm{NO}_{3}\right) 3$ & Organoclay & 0.0003 & $1.08 \mathrm{E}-06$ \\
\hline 4 & $2 M$ HDEHP $+\mathrm{Ce}\left(\mathrm{NO}_{3}\right) 3$ & Organoclay & 0.0010 & $3.83 \mathrm{E}-06$ \\
\hline 5 & $30 \% \mathrm{TBP}+\mathrm{Ce}\left(\mathrm{NO}_{3}\right) 3$ & Organoclay & 0.0184 & $2.69 \mathrm{E}-05$ \\
\hline 6 & $1 M$ HDEHP+Ce( $\left(\mathrm{NO}_{3}\right)$ & Grouted & 0.0079 & $5.00 \mathrm{E}-06$ \\
\hline 7 & $2 M \mathrm{HDEHP}+\mathrm{Ce}\left(\mathrm{NO}_{3}\right) 3$ & Grouted & 0.0516 & $4.53 \mathrm{E}-05$ \\
\hline 8 & $30 \% \mathrm{TBP}+\mathrm{Ce}\left(\mathrm{NO}_{3}\right) 3$ & Grouted & 0.1800 & 5.99E-05 \\
\hline 9 & Exxsol D60+Ce( $\left(\mathrm{NO}_{3}\right) 3$ & NA & 0.7830 & $5.87 \mathrm{E}-03$ \\
\hline 10 & $1 M \mathrm{HDEHP}+\mathrm{Ce}\left(\mathrm{NO}_{3}\right) 3$ & NA & 0.2200 & $6.98 \mathrm{E}-04$ \\
\hline 11 & $2 M$ HDEHP $+\mathrm{Ce}\left(\mathrm{NO}_{3}\right) 3$ & NA & 0.1220 & $4.71 \mathrm{E}-04$ \\
\hline 12 & $30 \% \mathrm{TBP}+\mathrm{Ce}\left(\mathrm{NO}_{3}\right) 3$ & NA & 0.0868 & $1.27 \mathrm{E}-04$ \\
\hline 13 & $1 M \mathrm{HDEHP}+\mathrm{Ce}\left(\mathrm{NO}_{3}\right) 3$ & Organoclay & 0.00393 & $1.25 \mathrm{E}-05$ \\
\hline 14 & $1 M \mathrm{HDEHP}+\mathrm{Ce}\left(\mathrm{NO}_{3}\right) 3$ & Grouted & 0.00953 & $6.01 \mathrm{E}-06$ \\
\hline
\end{tabular}

\section{CONCLUSIONS}

Solidifying the organic extractant solutions from the REDC hot cells, using either PM-199 Organoclay or grouting materials, would produce solid waste forms with no free liquid. Either method would produce waste that should qualify for disposal at the Waste Isolation Pilot Plant. The use of Organoclay would be much simpler to implement inside a hot cell. Granular Organoclay can be added to a container of organic waste solution until there is a dry layer on top of the liquid and then allowed to cure for a few hours. Grouting the liquids would require using multiple ingredients and mixing steps. Both methods produced waste forms that trapped cerium, as a surrogate for plutonium, inside the waste, with airborne release fractions during the fire scenario tests at well below the $10^{-4}$ used in the REDC DSA.

\section{REFERENCES}

US Department of Energy. Airborne Release Fractions/Rates and Respirable Fractions for Nonreactor Nuclear Facilities, Report no. DOE-HDBK-3010-94, US Department of Energy, Washington, DC, 1994.

Mishima, J. and L. C. Schwendiman, Some Experimental Measurements of Airborne Uranium (Representing Plutonium) during Burning of Contaminated Wastes, Report no. BNWL-1730, Pacific Northwest Laboratory, Richland, WA, June 1973. 
This page is intentionally left blank. 


\section{APPENDIX A. FLOW RATE AND TEMPERATURE DATA FOR EACH RUN}

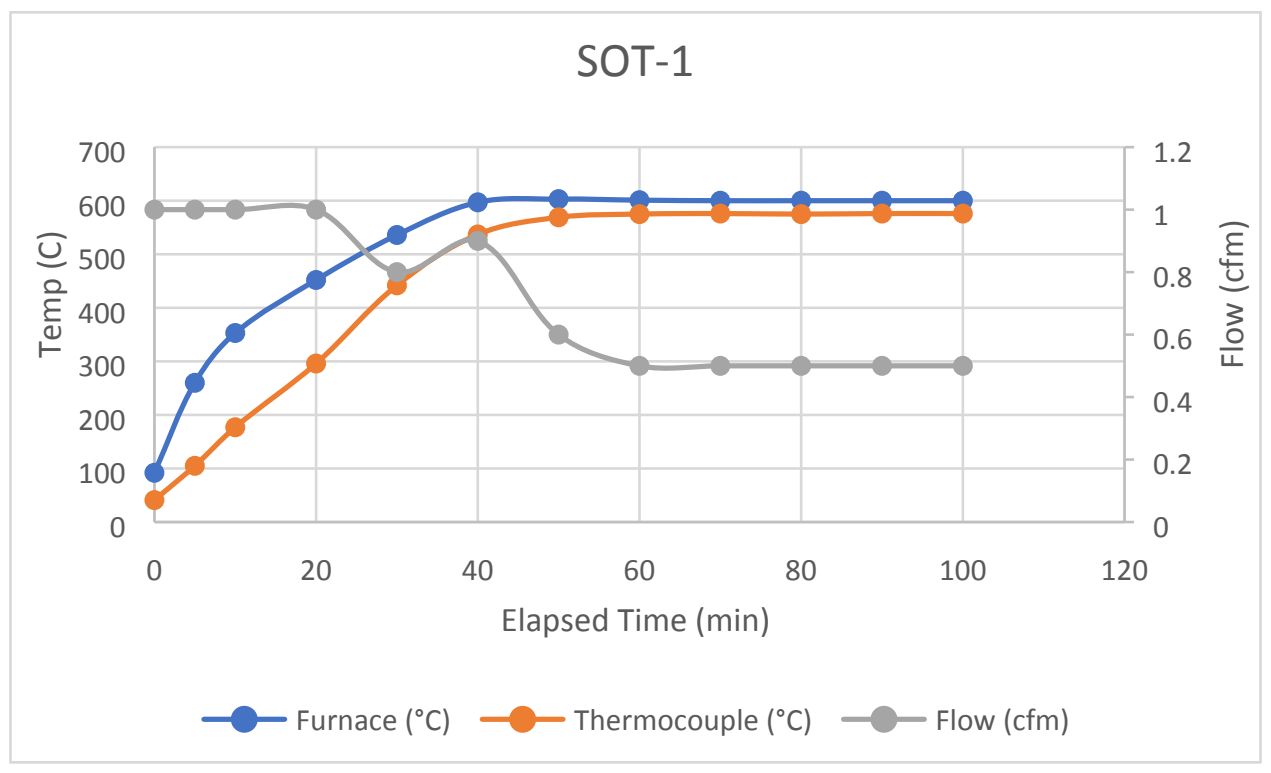

Figure A-1. Temperature and flow data for sample \#1. (See Table 3 for sample compositions)

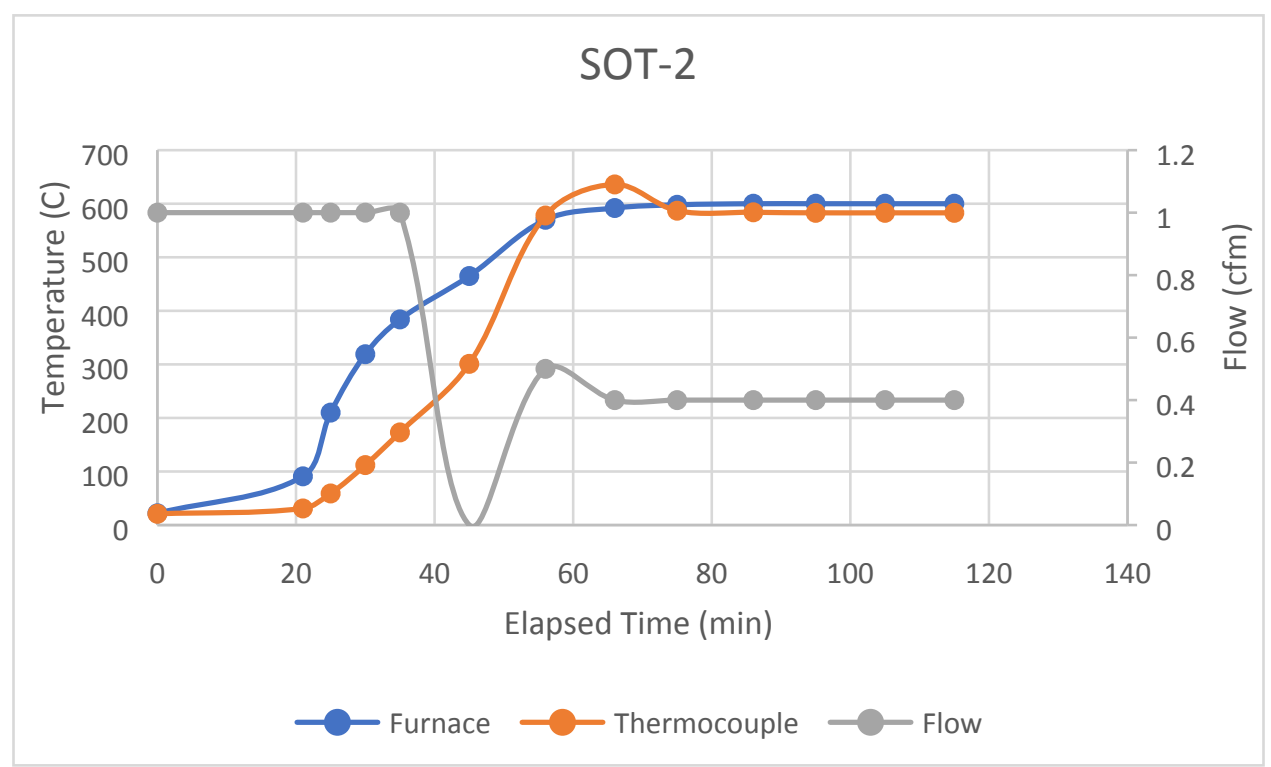

Figure A-2. Temperature and flow data for sample \#2. 


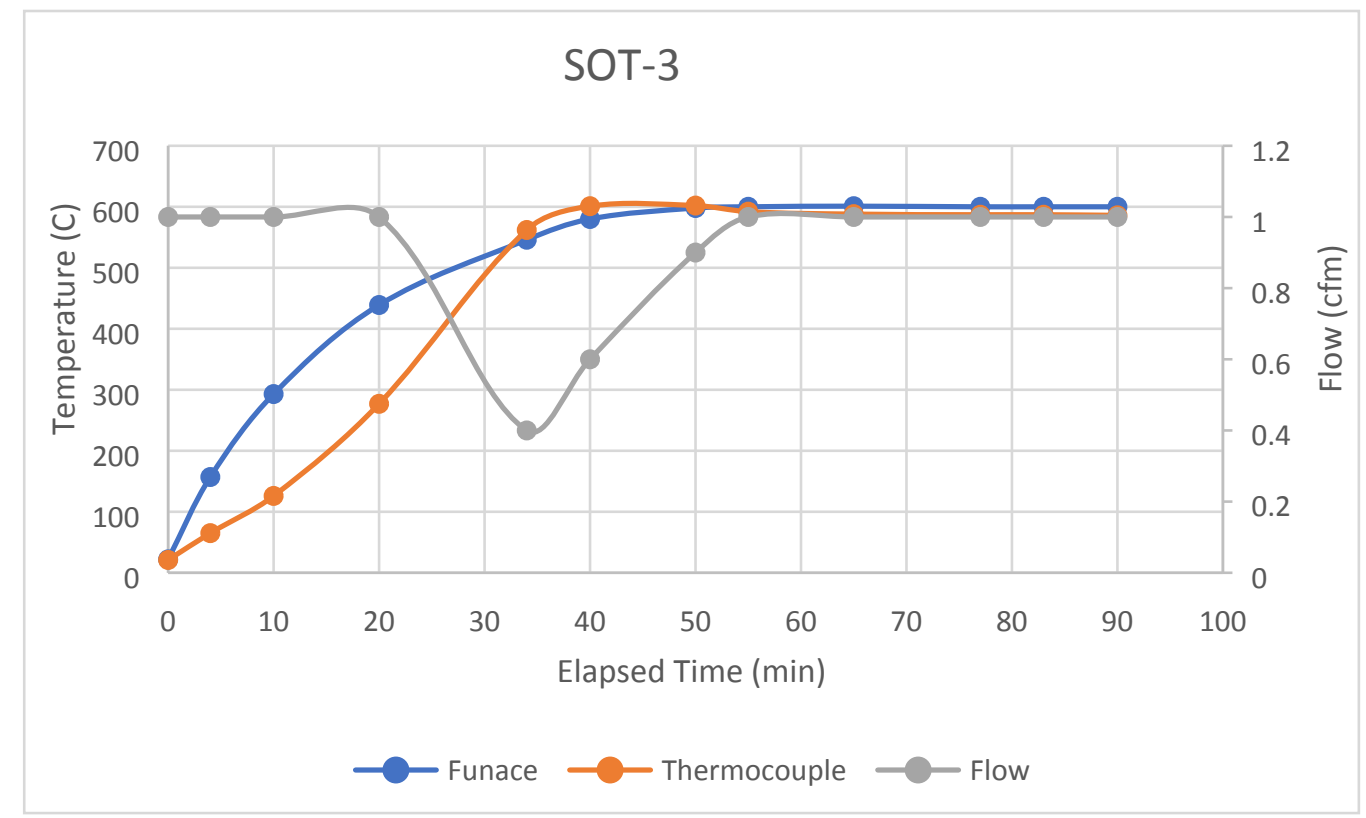

Figure A-3. Temperature and flow data for sample \#3.

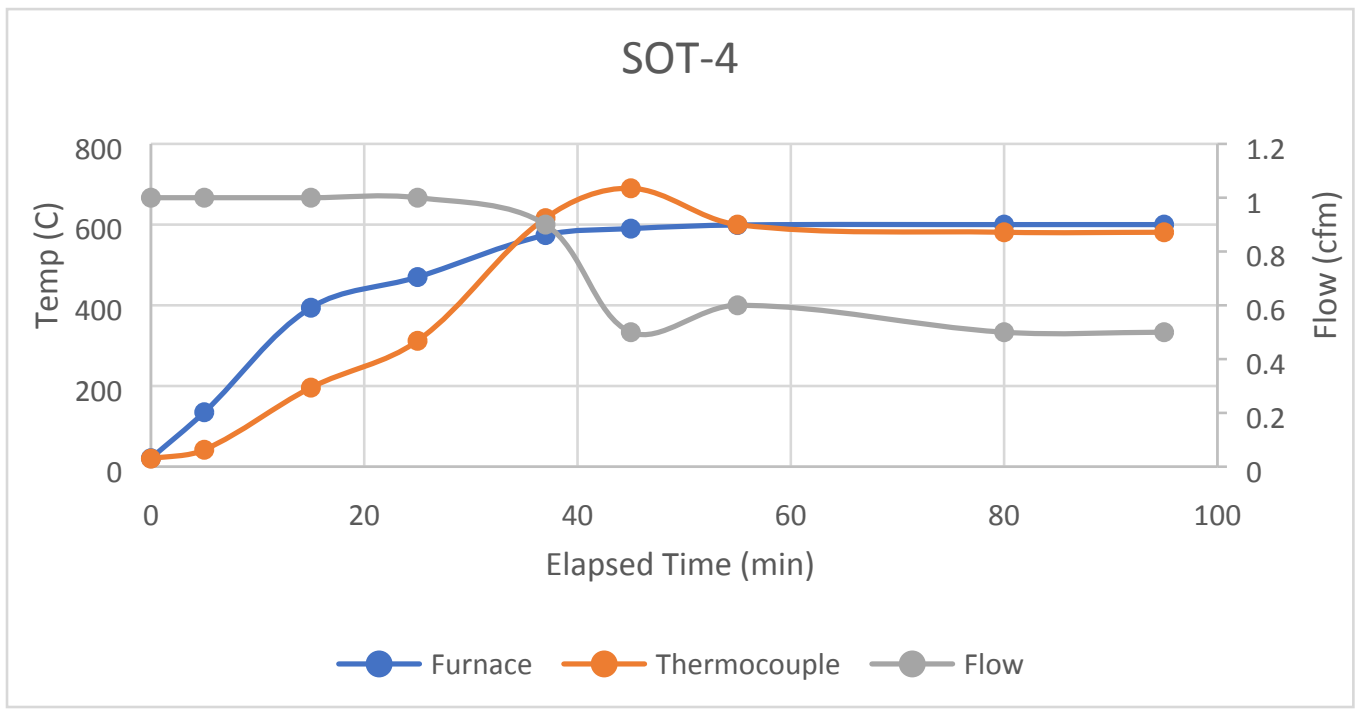

Figure A-4. Temperature and flow data for sample \#4. 


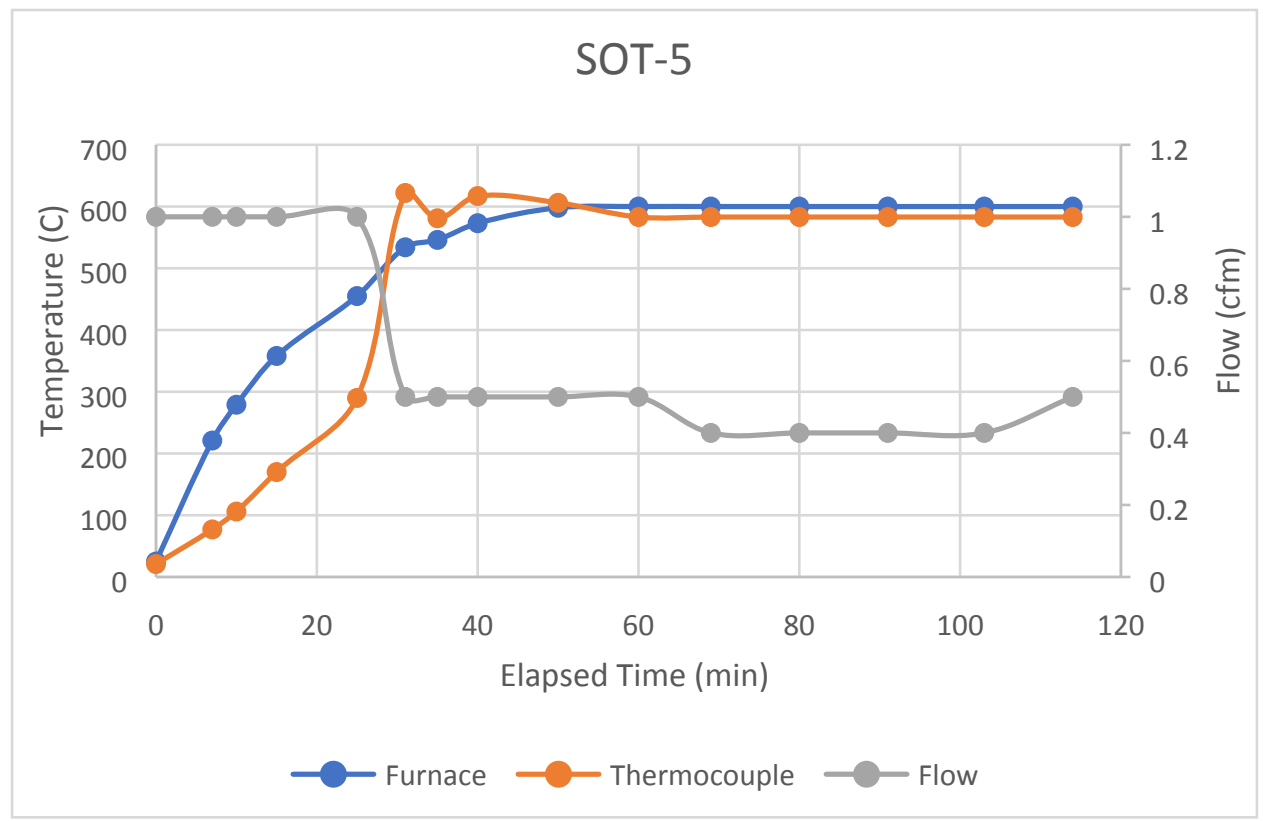

Figure A-5. Temperature and flow data for sample \#5.

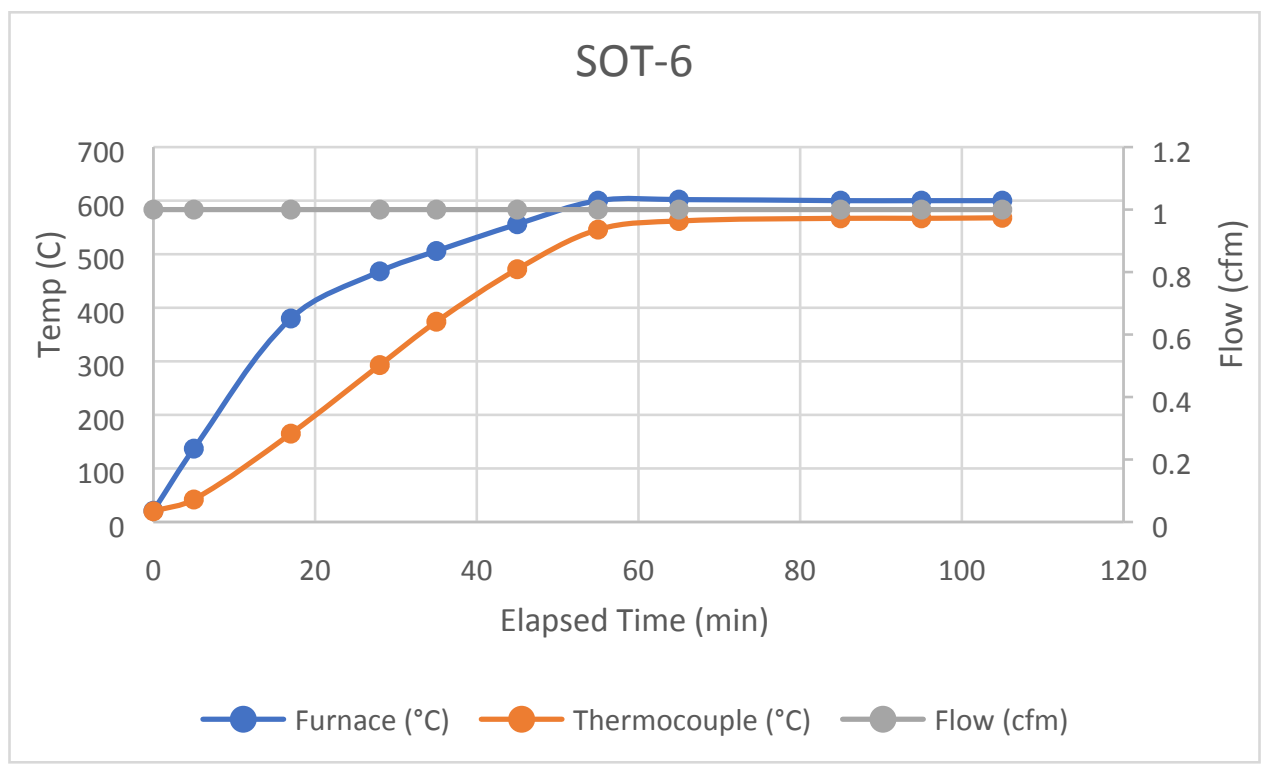

Figure A-6. Temperature and flow data for sample \#6. 


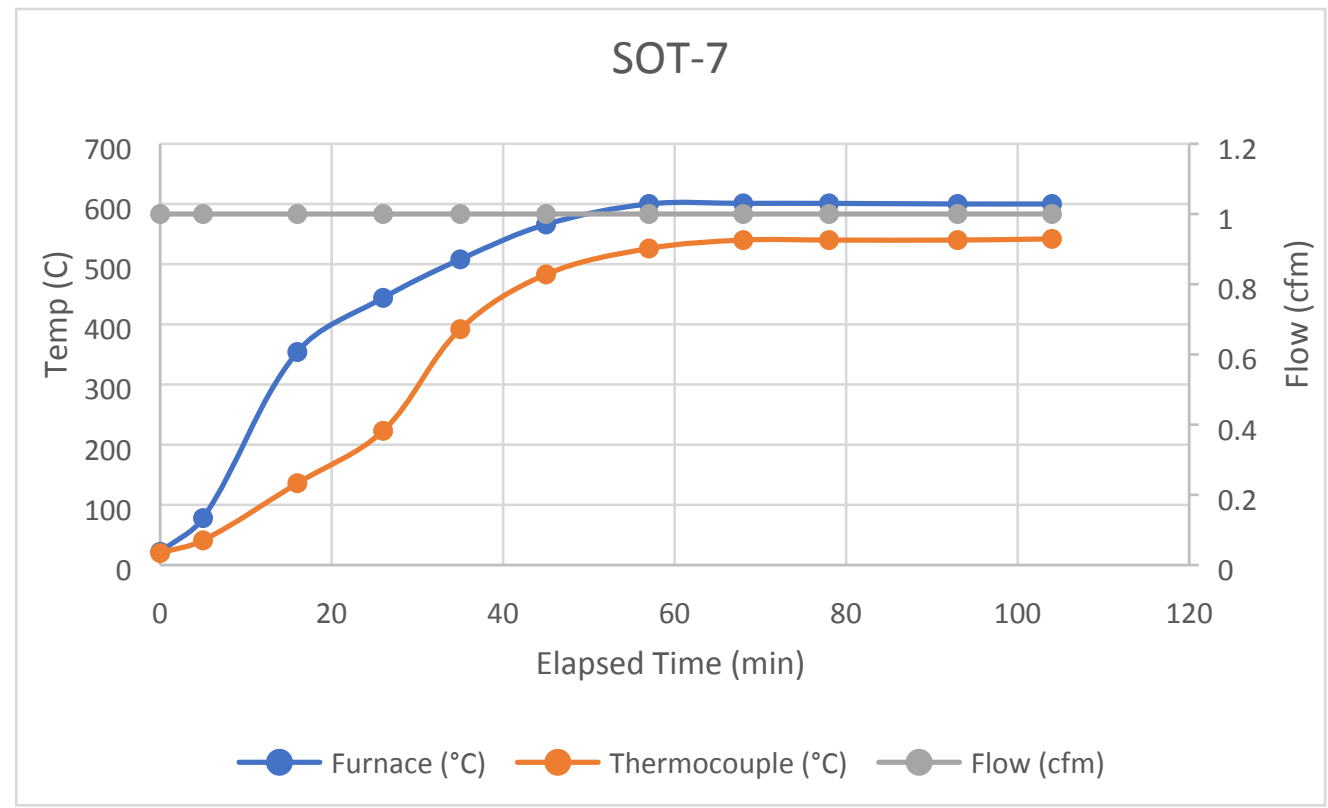

Figure A-7. Temperature and flow data for sample \#7.

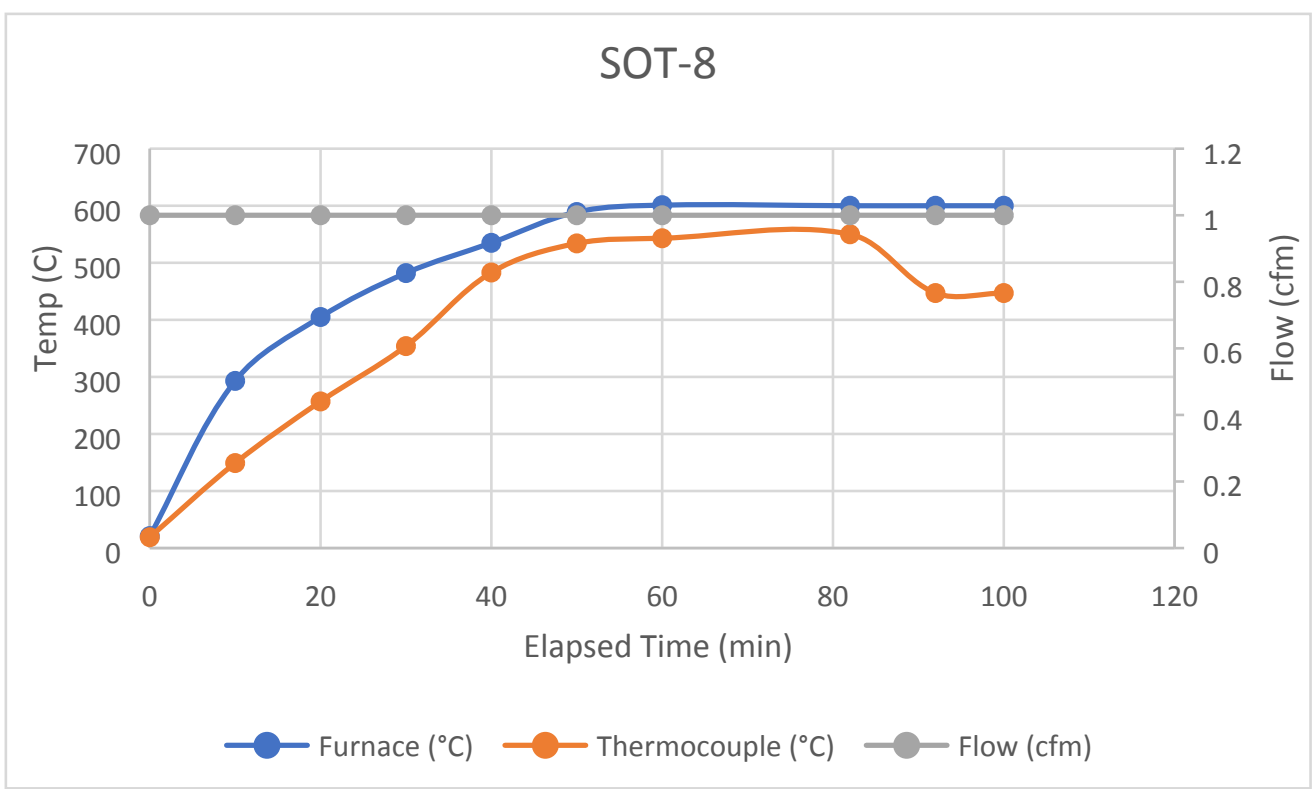

Figure A-8. Temperature and flow data for sample \#8. 


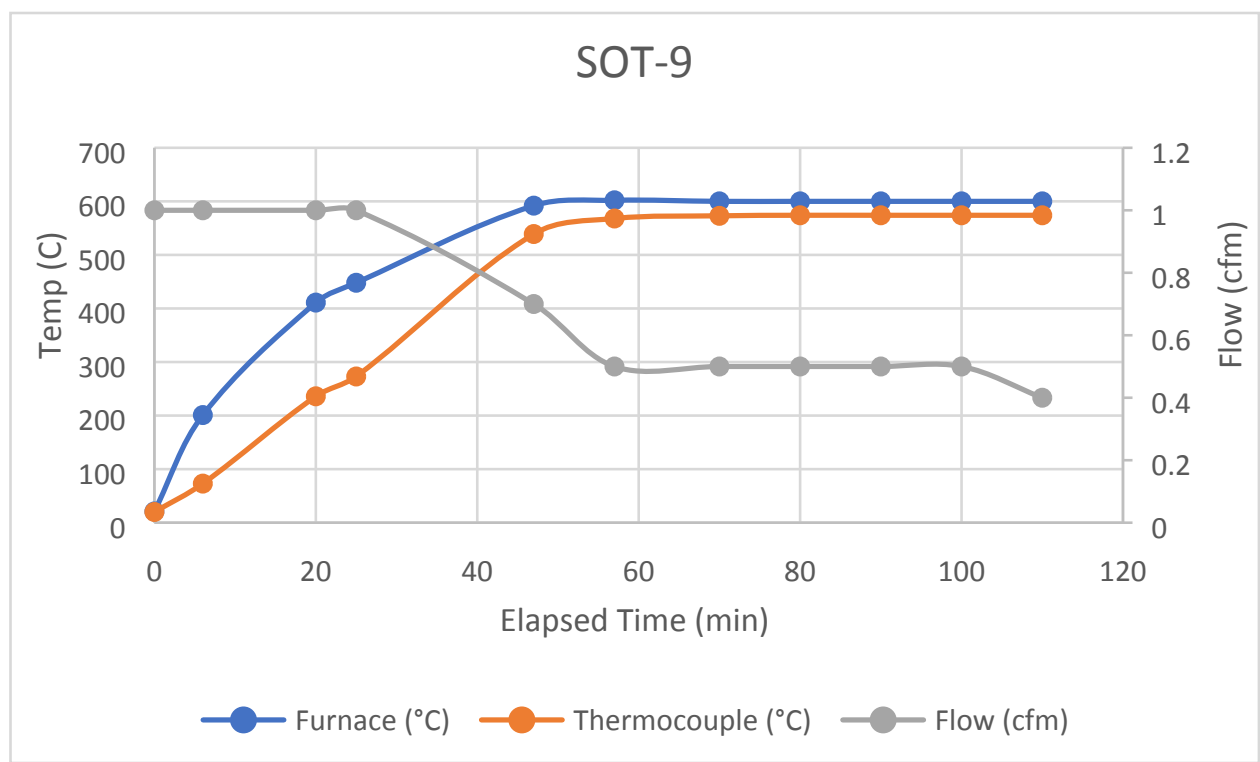

Figure A-9. Temperature and flow data for sample \#9.

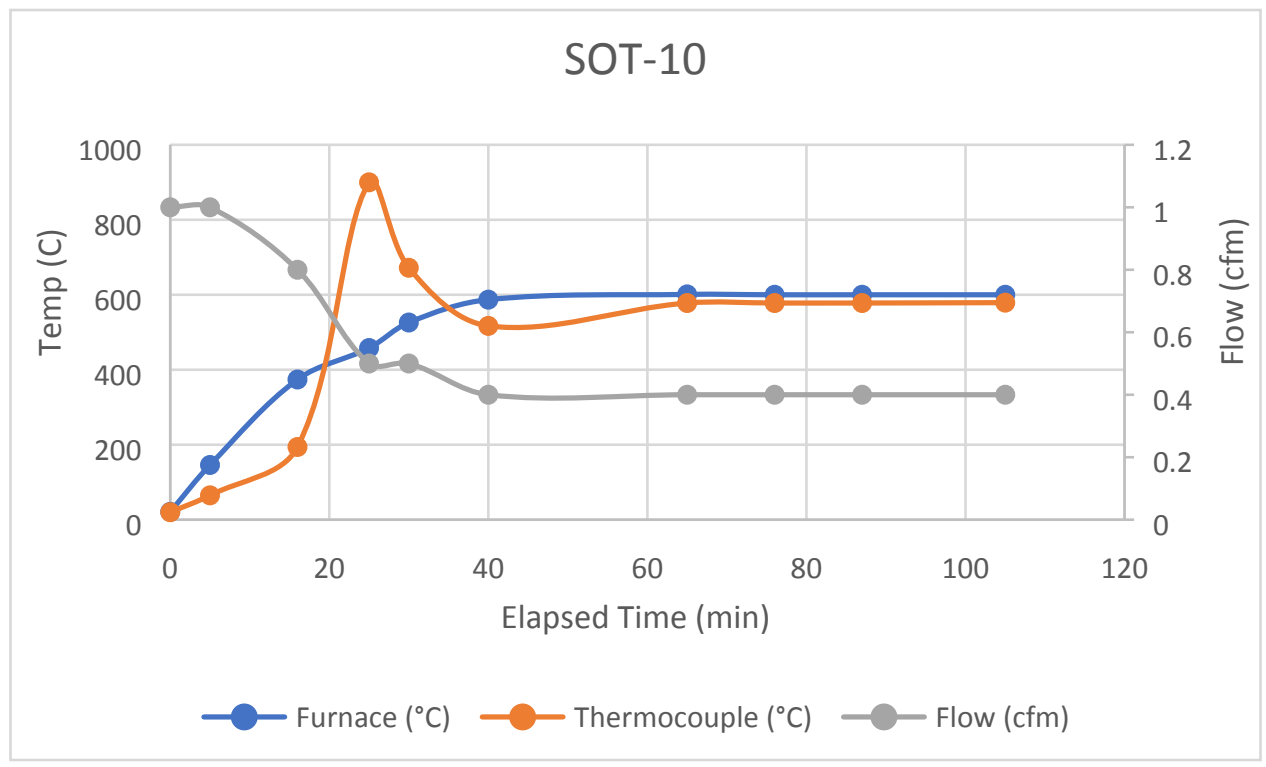

Figure A-10. Temperature and flow data for sample \#10. 


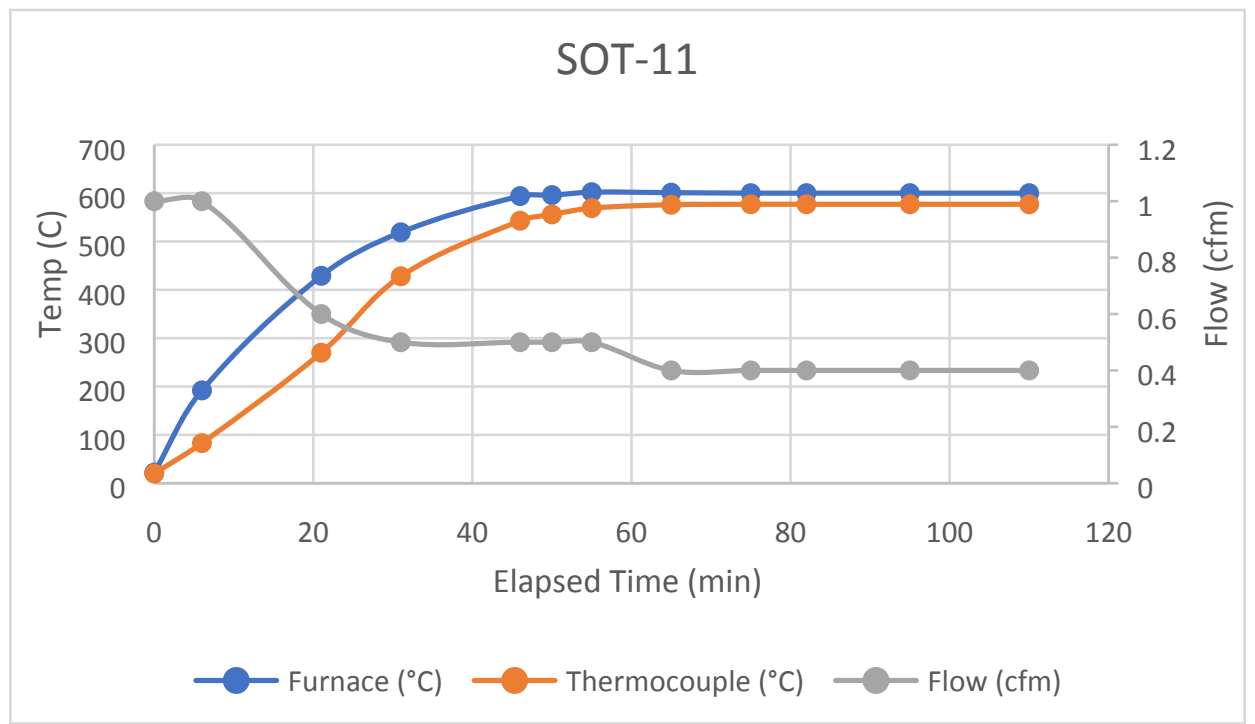

Figure A-11. Temperature and flow data for sample \#11.

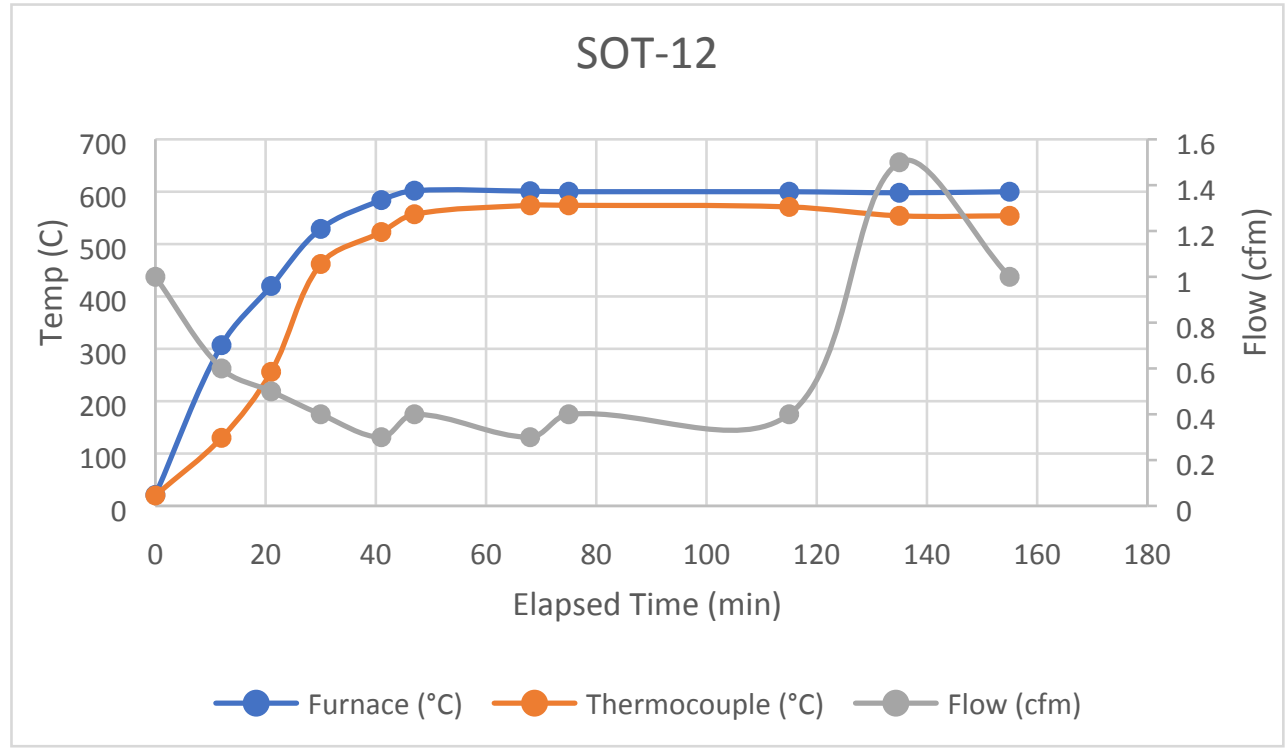

Figure A-12. Temperature and flow data for sample \#12. 


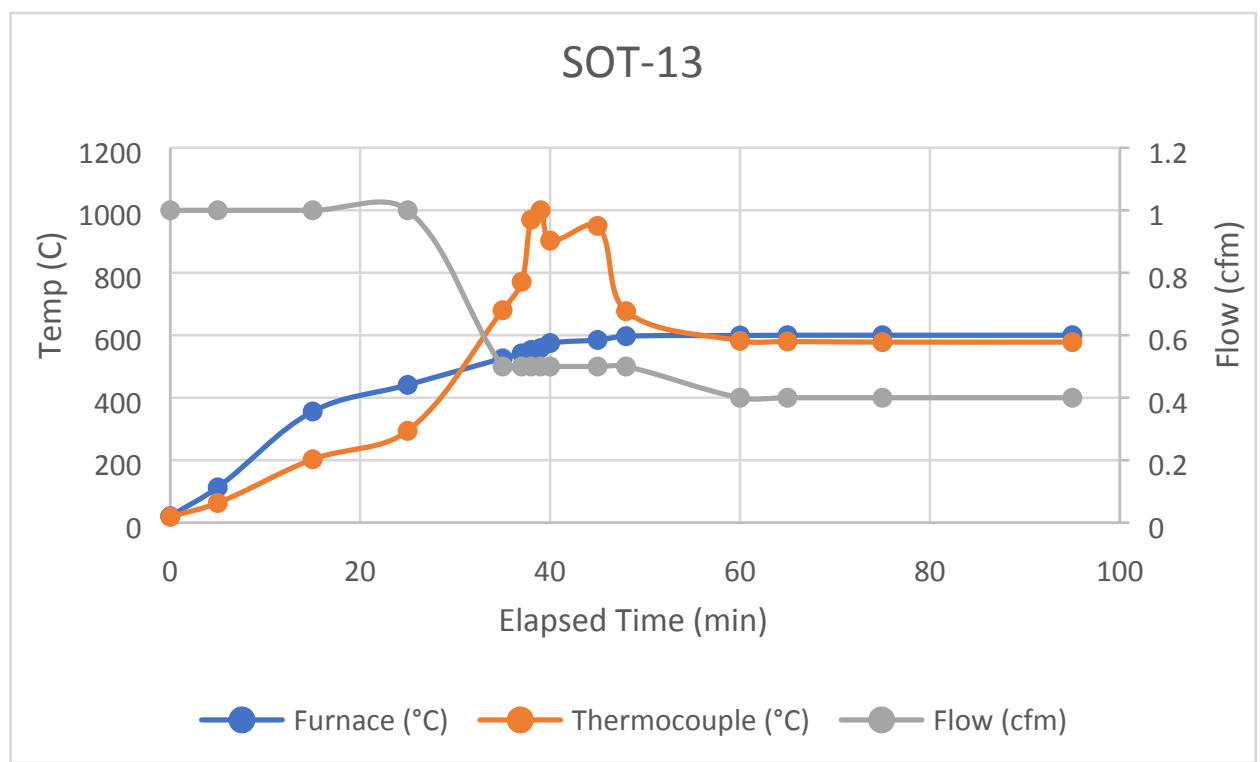

Figure A-13. Temperature and flow data for sample \#13.

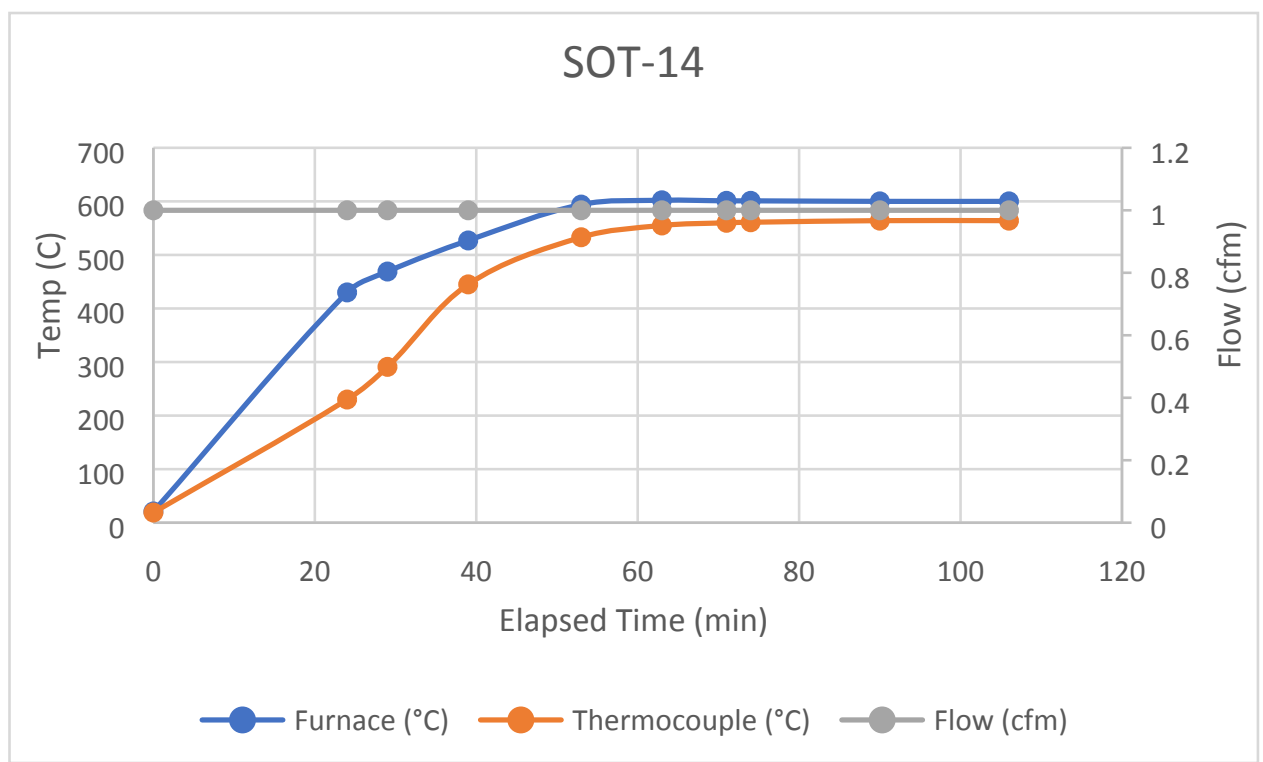

Figure A-14. Temperature and flow data for sample \#14. 
